\title{
Measuring Party Strength: a New Systematic Framework Applied to the Case of German Parties, 1991-2013
}

Paolo Chiocchetti

This is an Accepted Manuscript of an article published by Taylor \& Francis Group in German Politics on 12/01/2016, available online:

http://tandfonline.com/10.1080/09644008.2015.1124090

Version of Record: Paolo Chiocchetti (2016): Measuring Party Strength: A New Systematic Framework Applied to the Case of German Parties, 1991-2013, German Politics, DOI:

10.1080/09644008.2015.1124090

To link to this article: $\underline{\text { http://dx.doi.org/10.1080/09644008.2015.1124090 }}$

An appropriate quantitative measurement of party strength is an essential precondition to any further qualitative assessment of partisan influence. The existing literature offers a number of individual indicators but fails to integrate them into a coherent systematic framework. This article fills this gap by proposing a new multi-dimensional and multi-level framework model to operationalise and measure party strength. The soundness of the approach is tested on the case study of the evolution of German parties between 1991 and 2013.

\section{INTRODUCTION}

Political parties have been suffering since the late 1970s a generalised and substantial erosion of their electoral support, societal roots, legitimacy and ideological coherence. ${ }^{1}$ Despite their multi-faceted crisis, however, they continue to dominate state institutions and to represent the main formal linkage connecting the state and its citizens. ${ }^{2}$ The study of party strength thus seems to retain all its interest.

The purpose of the present article is to move forward the debate on the conceptualisation and measurement of the quantitative aspects of party strength. I propose to overcome the shortcomings of existing quantitative indicators by adapting and integrating them into a systematic, multi-dimensional and multi-level framework. This will enable scholars of party politics to measure party strength within individual components more accurately and to obtain meaningful estimates of overall party strength, thus providing a firmer foundation for a broad range of empirical studies on party influence.

The article is organised as follows. In the first section I discuss the relevant literature on party strength, present a new systematic framework to operationalise it and an associated set of quantitative indicators to measure it and review its main features, advantages, problems and limits. In the second section I then test the soundness of the approach on the case study of the evolution of German parties in the period 1991-2013. 


\section{PARTY STRENGTH: BACKGROUND, CONCEPT AND OPERATIONALISATION}

\section{Parties as Power-seeking Actors}

The literature on political parties has identified a number of possible subjective goals guiding parties' behaviour. Müller and Strøm distinguish between (executive) "officeseeking", "policy-seeking" and "vote-seeking aims". ${ }^{3}$ Harmel and Janda add to this a new aim concerned with the "representation/participation of members". ${ }^{4}$ These objectives, however, are generally but instrumental steps toward a different set of end goals, as the abovementioned authors openly acknowledge. "Party only seek votes to obtain policy influence, the spoils of office, or both", claim Müller and Strøm. ${ }^{5}$ Intraparty democracy maximisation is arguably better conceived as an organisational choice than as a party goal. ${ }^{6}$ In any case, the participation of members themselves tends to be motivated either by collective incentives related to the party ideological/policy goals or by selective incentives concerning material and status rewards. ${ }^{7}$ Finally, office itself may be valued for its "rewards [...] intrinsically" or "only instrumentally for the ability it gives to influence policy outputs". ${ }^{8}$ We are therefore left with two main categories of end goals, which might be called public influence and private rewards. ${ }^{9}$ On the one hand, parties strive to shape public policy, institutions and, more broadly, social relations according to specific interests and beliefs. Precisely whose interests and beliefs and they serve and how, depends from the context (e.g. ideological currents, social groups or more unstable constellations of voters' preferences).${ }^{10}$ On the other hand, parties also function as machines to obtain and distribute private benefits to their member and close supporters; in the words of Max Weber, "to attain ideal or material advantages for its active members", ${ }^{11}$ for instance personal influence, social status and recognition, psychological rewards, employment, money and favours. In the actual practice the two goals are intimately connected, as the successful acquisition of private benefits by party cadres is ultimately dependent on winning the support of civil society actors (e.g. voters, members and financers), while the aggregation and representation of collective interests can hardly take place in absence of formal organisations defining common interests, goals and strategies and with the human and material means to pursue them. ${ }^{12}$

In order to pursue both kinds of end goals, however, political parties need to first concern themselves with the acquisition of resources of political power ${ }^{13}$, understood as the assets needed to ensure their existence and increase their potential influence on the political system and society. It is therefore possible abstract from questions of ultimate motives, ideological orientation and sociological composition and to consider parties simply as power-seeking actors trying to maximise their control on these resources. Such control is here defined as party strength. A variety of such resources has been discussed in the literature on party goals and on political parties, the most important being: electoral resources, which in democratic systems are the main expression of their legitimacy and popular support; ${ }^{14}$ institutional resources, i.e. the control over public offices (e.g. parliaments, governments and presidencies), other state appointments and the recruitment of advisors, civil servants and employees of public and semi-public enterprises; ${ }^{15}$ organisational resources, understood in terms of cohesion, members, activists, collateral organisations, staff and finances; ${ }^{16}$ and communication resources, particularly autonomous propaganda and coverage in the mass media. ${ }^{17}$

The acquisition of resources of political power does not immediately coincide with an increase of power. If we accept Russell's traditional definition of power as the "production of 
intended effects", 18 what matters most is the ability of a party to translate abstract power into actual influence by means of appropriate activities, tactics, strategies and so on. Thus, an entry into the study of partisan power can be found both from the point of view of its preconditions and from that of its outcomes. ${ }^{19}$ I follow here the former path and focus on party strength defined as the successful acquisition of resources of political power. The advantage of this choice is that it allows to measure party strength with quantitative indicators, producing precise and relatively objective results. While not exhausting the study of party power, an appropriate operationalisation and measurement of party strength does provide important indications of its levels and distribution and represents a crucial foundation for any serious further analysis of the translation of abstract strength into actual influence.

\section{Operationalising Party Strength}

In the previous subsection I have argued that political parties tend to pursue two kinds of end goals (public and private), that in order to do that they need power, and that one of major aspects of it is the acquisition of resources of political power. The outcome of this undertaking has been defined as party strength. While a great deal of theoretical and empirical literature on political parties deals explicitly or implicitly with party strength, existing attempts to operationalise this concept in quantitatively measurable ways are subject to a number of weaknesses.

The first problem is that indicators have indeed been developed to measure party strength within individual components, but they have never been systematised into a coherent analytical framework; this leads to discrepancies and gaps, hampering the comparison of party strength across components. In response to these problems, I have developed a systematic framework of party strength offering four improvements on the existing state of scholarship. Firstly, I clarify that there are three main ways to measure the levels and variations over time of party strength: in absolute terms (resources), in relative terms vis-àvis the party system (systemic strength) and in relative terms vis-à-vis society at large (societal strength). Note that, within the same political system, all three methods lead to the same ranking of parties. This is not the case for international comparisons, where the methods lead to different results and must be chosen according to the purpose of the analysis. Secondly, I streamline existing indicators into a coherent model with four components, developing new indicators when no satisfactory alternative already exists (notably, for governance and financial strength). Thirdly, I expand and harmonise the coverage of the individual indicators. Ideally, each of them should encompass the entirety, or a reasonably comprehensive amount, of the resources of the component it purports to measure. This is however rarely the case, with indicators of electoral, governance and financial strength generally relying on a single narrow subset of them (e.g. first chamber votes, first chamber seats, national cabinet seats or incomes of the party-organisation). In order to obtain reasonable estimates of party strength in these components I proceed in the following way. In the case of financial strength, I include the incomes of the partyorganisation, the net assets of the party, the incomes of national and regional elected representatives and of their parliamentary groups and the incomes of party-near foundations. All these resources are homogeneous and can be simply summed to each other. In the other two cases, I deem the inclusion of (at least) all directly elected representative assemblies and monocratic positions at both national and regional level 
essential. These resources are however are inhomogeneous, as they refer to levels of governance (national and regional) and bodies (first and second chamber, monocratic positions) of different significance; party strength must therefore be measured with weighted indicators accounting for the relative importance of the level or body in question. Fourthly, I harmonise the temporal scope of the individual indicators. These often do not refer to the same temporal scope, with financial accounts expressing the incomes of the whole year, membership figures the numbers on the $31^{\text {st }}$ of December, electoral figures the results on the day of the election, and so on; I express them all in end-of-the-year yearly rolling figures. ${ }^{20}$

The second problem is that no indicator has ever been devised to measure overall party strength. The issue has been pointed out with reference to organisational power by Ignazi, who has advocated the development of a "combined measure" encompassing human, financial, collateral and communication resources. ${ }^{21}$ In the same vein, I plead for the necessity of indicators of overall party strength accounting for the largest possible spectrum of resources pursued by political parties. Unfortunately, some arguably important components are not (yet?) liable to an operationalisation out of theoretical and practical problems: for example, the bonds between parties and the organised civil society, the media coverage on political parties, party influence within the non-elective sections of the state (e.g. the bureaucracy, the judiciary, the military or hereditary offices) and the entrenchment of policy preferences in higher-level norms (e.g. constitutions) and jurisprudence. In all these components the development of adequate indicators is hampered both by the lack of sufficiently comprehensive data and by the difficulties in accounting for the eminently qualitative character of these resources. The second-best option consists in identifying a range of selected resources possessing the following characteristics: being quantifiable; being of high and proven importance to parties as means of survival and influence; covering a broad and balanced spectrum of distinct components. I propose to do this by building composite indicators of party strength based on four components (resources): electoral (votes), governance (relevant parliamentary seats), participatory (members) and financial (money). I believe that this selection offers a reasonable approximation of party strength, as it encompasses most key objects of party efforts generally identified in the theoretical and empirical literature while providing a fairly balanced mixture of indicators of institutional strength, organisational strength and public support.

The result of these operations is a systematic framework operationalising party strength as the combination of four components and providing an associated toolkit of fourteen indicators, three for each component (electoral, governance, participatory and financial) and two for overall party strength (systemic and societal). ${ }^{22}$ The indicators selected for each component are summarised in Table 1; their construction and methodological issues are discussed in the following paragraphs. 
TABLE 1. PARTY STRENGTH: COMPONENTS AND INDICATORS

\begin{tabular}{|c|c|c|c|}
\hline COMPONENT & $\begin{array}{c}\text { ABSOLUTE STRENGTH } \\
\text { (n.) }\end{array}$ & $\begin{array}{c}\text { SYSTEMIC STRENGTH } \\
(\%)\end{array}$ & $\begin{array}{c}\text { SOCIETAL STRENGTH } \\
(\%)\end{array}$ \\
\hline $\begin{array}{l}\text { A. ELECTORAL } \\
\text { STRENGTH }\end{array}$ & $\begin{array}{c}\text { votes } \\
\circ\end{array}$ & $\begin{array}{c}\text { votes / total valid votes } \\
\circ\end{array}$ & $\begin{array}{c}\text { votes / eligible voters } \\
\circ\end{array}$ \\
\hline $\begin{array}{l}\text { B. GOVERNANCE } \\
\text { STRENGTH }\end{array}$ & $\begin{array}{c}\text { relevant parliamentary } \\
\text { seats } \\
\bullet\end{array}$ & $\begin{array}{l}\text { relevant seats / } \\
\text { total relevant seats }\end{array}$ & $\begin{array}{l}\text { governance systemic strength * } \\
\text { state expenditures / GDP }\end{array}$ \\
\hline $\begin{array}{l}\text { C. PARTICIPATORY } \\
\text { STRENGTH }\end{array}$ & members & members / total members & members / eligible voters \\
\hline $\begin{array}{l}\text { D. FINANCIAL } \\
\text { STRENGTH }\end{array}$ & $\begin{array}{c}\text { incomes and net assets } \\
0 \\
\end{array}$ & $\begin{array}{c}\text { incomes and net assets } \\
\text { / total incomes and net } \\
\text { assets } \\
0\end{array}$ & incomes and net assets / GDP \\
\hline $\begin{array}{l}\text { OVERALL } \\
\text { STRENGTH }\end{array}$ & - & average of all dimensions & $\begin{array}{l}\text { average of all dimension } \\
\text { (index with base-year) } \\
\end{array}$ \\
\hline
\end{tabular}

Notes: • new indicator; o partially modified indicator; all other indicators are commonly in use.

Electoral strength refers to the success of a party in winning popular support. I choose to operationalise it in terms of votes obtained in free and fair direct elections for parliamentary or governmental offices. An alternative possibility would be to select instead forms of support measured through modern public opinion techniques such as voting intentions or approval ratings. ${ }^{23}$ Despite the growing role played by opinion polls in guiding political decisions and the public debate, I reject the adoption of these indicators because of their numerous disadvantages: on the one hand, they are subject to statistical errors, sampling errors and misreporting by respondents; on the other hand, they reflect more superficial and volatile preferences than those expressed through the formal act of voting. Electoral strength will therefore be measured with the following indicators: in absolute terms, with the number of votes received; with reference to the party system, with the vote share (votes / total valid votes); with reference to society as a whole, with the electorate share (votes / eligible voters). The electoral component requires weighted indicators encompassing elections for all legislative bodies and monocratic positions at both national and regional level, each weighted for its relative importance. The measurement and interpretation of these indicators is not excessively problematic: electoral results are usually reliable and readily available and known issues are numerous ${ }^{24}$ but tend to be of limited magnitude.

Governance strength refers to the success of a party controlling the state institutions, particularly the elective ones. A substantial number of indicators have already been proposed in this component. ${ }^{25}$ Parliamentary strength has been measured with the simple "seat share", with game-theoretical power indices (e.g. Banzhaff), or with weighted measures accounting for the different relevance of majority and opposition seats (e.g Blau's "legislative power"). The first method is to be preferred from the perspective of this article, as it capture better the ex-ante potential benefits of parliamentary seats. Governmental strength has been measured with the simple "cabinet share" of parliamentary seats (including either only the parties actually represented in the cabinet or all the parties supporting it, directly or externally), with the unweighted "proportional tenure" (Taylor and Lijphart) or with the "share of cabinet seats" (Vowles). The preferable method is again the cabinet share of parliamentary seats including all government-supporting parties, because the abstract (and often actual) balance of power within a cabinet seems to be roughly proportional to this ratio. ${ }^{26} \mathrm{~A}$ separate calculation of parliamentary and governmental 
strength, however, is of little use for my purpose, as in most democracies parliaments and governments are intertwined bodies responsible to each other (in presidential systems this is not the case, but the cabinet still needs a parliamentary support to carry out substantial parts of its programme) and contributing in their specific ways to common purpose, the production of policy outputs. It appears therefore more reasonable to encompass both subcomponents with a combined measure, defined here as governance strength. My proposed solution, based on the combination and adaptation of the above-mentioned methods, adheres to the following principles. Firstly, governance strength is operationalised in terms of "relevant" seats, which are defined as the seats of parties belonging to the governmentsupporting coalition only (either actually represented in the cabinet or supporting it externally) for the governmental sub-component and as the seats of all parties represented in parliament for the parliamentary sub-component. Secondly, partially following Blau, the combination of the two sub-components will not be fixed and will vary dichotomically according to the size of the government-supporting coalition: if it enjoys a parliamentary majority, the governmental sub-component will get the lion's share; if the cabinet is a minority one, the opposite distribution will occur. Thirdly, the further weighting of multiple bodies of each component (e.g. two chambers or, in presidential and semi-presidential systems, a directly elected president and a cabinet) and of each level (national and regional) will be done according to their relative importance. Fourthly, as a proxy for the overall influence of state institutions on society I propose to use the ratio between states expenditures and the gross domestic product. Governance strength will therefore be measured as follows: in absolute terms, with the number of relevant seats; in terms of systemic strength, with the share of relevant seats (relevant seats / total relevant seats); in terms of societal strength, by applying the latter indicator to the share of state expenditures (governance systemic strength * state expenditures / GDP). Despite their complexity, the indicators proposed seem to capture well both the relative control of parties over public offices and their overall potential influence over society at large. Data on parliamentary seats and governmental coalitions are usually reliable and unequivocal, except in cases of external supports without formalised agreements. The only serious methodological problem concerns the exact weighting of each body, level and sub-component (parliamentary and governmental), which to some extent relies on a subjective assessment. ${ }^{27}$

Participatory strength refers to the success of a party in developing strong individual bonds of support, affiliation and involvement going beyond the mere act of voting. Many such relations exist and constitute in theory a reasonable basis for an operationalization: for instance, the links between a party and its full-time activists, its active members, its formal membership, its active sympathisers or the "party identifiers". ${ }^{28}$ I opt for indicators based on formal membership figures on the grounds that partisan identification is the expression of too impalpable a relation, which does not necessarily involve any concrete act of support for the party in question, and that other relations are generally not quantifiable due to the lack of sufficiently comprehensive data. Consequently, participatory strength can be expressed in absolute terms with the number of members, in terms of systemic strength with the share of members (members / total members) and in terms of societal strength with the $\mathrm{M} / \mathrm{E}$ indicator (members / eligible voters). Eventual multiple subsets of membership figures can be added to each other without weighting. The value of these indicators suffers from two main problems. On the one hand, what being a party member concretely means (e.g. the average level of commitment) varies in each country and individual organisation. On the other hand, membership figures may be inflated or altogether missing for certain years and 
organisations, as they are usually based on uncontrollable voluntary declarations or estimates.

Financial strength refers to the capacity of parties to attract material resources - monetary or in kind. This component can be operationalised in a number of ways, for instance on the basis of campaign expenditures, yearly expenditures, yearly incomes or net assets. ${ }^{29}$ Partially departing from the common usage, I suggest doing it on the basis on yearly incomes plus net assets at the end of the previous fiscal year, which capture well the total amount of resources available to a party for consumption or saving. Financial strength can therefore be measured as follows: in absolute terms, with the amount of financial resources available (yearly incomes and net assets); in terms of systemic strength, with the share of financial resources (yearly incomes and net assets / total yearly incomes and net assets); in terms of societal strength, with the share of financial resources on the gross domestic product (yearly incomes and net assets / GDP). Subsets of financial figures can be summed without weighting. In the calculation of the indicators attention must be paid to add the broadest possible number of financial resources, which are often not included in the yearly financial statements of the parties; in particular, the incomes of MPs and parliamentary groups at both national and regional level. The value of the indicators may be somewhat problematic, as figures generally tend to be understated due to irregular reporting (financial statements are rarely subjected to stringent controls), black funds and accounting practices. In particular, resources made available to parties without charge by their own members, by the state or by collateral and friendly organisations (e.g. volunteer work, office and meeting spaces and favourable media coverage) always escape quantification.

Finally, overall party strength refers to the success of a party in acquiring the entire range of politically relevant resources. I propose to operationalise it in terms of unweighted averages of the four above-mentioned components: electoral, governance, participatory and financial. All the components so far discussed are, properly speaking, incommensurable: they refer to qualitatively different kinds of resources, expressed with different units of measurement and lacking clear conversion rates or a common universal equivalent. As a consequence, an indicator of overall party strength in absolute terms is a logical impossibility. Overall party strength in systemic terms, on the contrary, can be easily expressed by a composite indicator built as the unweighted average of all available components. Overall party strength in societal terms, finally, may be measured for certain purposes only. An unweighted average of the various systemic shares has little meaning in itself, as each individual share measures a unique kind of relation between a party and society. When expressed in terms of indexes with a common base-year, however, they too can be aggregated into a composite indicator offering a syntetic expression of the overall direction of these relations, and therefore of the rise or decline of partisan strength vis-à-vis society at large. Theoretically, it is not clear whether all components should carry the same weight or whether they should be attributed a differential importance - in general and over time. The option of not weighing the components should in my opinion be preferred on the ground of the absence of substantial evidence in favour of alternative choices. While governance strength may seem prima facie to be the single most important component, the empirical analysis of Müller and Strøm has established that vote-seeking behaviour is at least as prevalent among party leaders. ${ }^{30}$ Political parties of advanced economies have been experiencing since the late 1970s a rapid and nearly universal membership decline; ${ }^{31}$ nevertheless, membership size still matters on many grounds (to sustain the party organisation, to consolidate electoral gains, to carry on effective extra-parliamentary strategies and to influence the public discourse). Finally, the 
availability of large financial resources may in certain conjunctures even be detrimental to the public image of parties, but it remains essential to their organisational survival and development and looms large in the calculations of both the party in central office and the party in public office. ${ }^{32}$ As already remarked, these indicators fail to account for important power resources, particularly collateral linkages with civil society organisations and social movements, the control of the public debate through traditional, mass and new media and the control of non-elective state organs. I am nevertheless confident of their value as adequate approximation of overall party strength and as substantial improvements over the default alternative, that is assessing party strength on the basis of a single layer of a single component (e.g. first chamber votes, first chamber seats or national cabinet seats).

\section{Applications and Limits}

The proposed framework and associated toolkit of quantitative indicators can be usefully applied to a wide range of empirical analyses on the amount of resources controlled by parties (absolute strength), on their relative distribution within the political system (systemic strength) and on the strength of parties within society at large (societal strength). In particular, it enables one to compare in a consistent manner variations of party strength over time, across nations and across four components (electoral, governance, participatory and financial) and to obtain benchmark values for overall party strength. The framework is best adapted to the analysis of parties within democratic systems. The analytical value of the indicators proposed, of course, ultimately relies on the scope, quality and reliability of the primary data available and on the reasonableness of the weighting process, particularly in determining the relative importance of each electoral series (e.g. first chamber, second chamber, regional assemblies and presidential votes), of each relevant governance body, and of each component of overall strength (which are here considered equally important).

The framework can be subjected to a number of criticisms.

A first group of objections, which deals with the selection of relevant components and their operationalisation, has been answered in the previous sub-section.

A second group of objections deals with the choice to approach party power from the point of view of its ex-ante resources rather than of its ex-post effects. This is justified by my identification of three separate stages in the analysis of partisan power, which are complementary but must be kept distinct. The first stage refers to the mere acquisition of relevant resources; the second to the ways in which they are actually employed by parties; the third to the outcomes of their use, i.e. the ultimate success or failure in translating abstract power into actual influence. Analyses focusing on the intrinsically or situationally unequal qualitative importance of specific resources (e.g. coalition and blackmail potential, pivotal role for governmental formation, party cohesion or Banzhaf power indices) $)^{33}$ properly belong to the second stage. Ex-post analyses of actual influence (e.g. conflictwinners or veto-players) ${ }^{34}$ to the third. Both have been excluded from my analysis, which aims to provide an accurate measurement of the ex-ante control on resources of political power. In my opinion this constitutes a necessary precondition of subsequent stages of analysis. More specifically the indicators, beyond their intrinsic interest as measures of abstract ex-ante strength, may provide the foundation to develop modified measures accounting for the above-mentioned second-stage qualitative issues and a useful benchmark for quantitative and qualitative assessments based on ex-post methodologies. 
A third very serious objection is the explicit or implicit claim of several scholars that the study of party strength is largely redundant, insofar as the essential features of the political process would be actually shaped not by parties but by other policy-makers or by impersonal processes. Schonfeld's devastating review of the functionalist literature, for instance, concludes that "the researcher identifies a function (or a set of functions) of parties viewed as crucial for the political system; evidence and analysis lead to the conclusion that this function (these functions) is (are) not performed or not performed well" ${ }^{35}$ Other scholars have pointed out the relative powerlessness of political parties in shaping policy outputs visà-vis the actions of the state bureaucracy, interest groups, social movements, charismatic or technocratic leaders, the judiciary, foreign states, supranational institutions, and transnational industrial or financial conglomerates. ${ }^{36}$ These critiques are in my opinion broadly correct in pointing to the limits of party politics but, in my opinion, do not make its study redundant: far from replacing political parties, all these influences typically continue to operate through their interface. The main question is therefore not if parties are powerless, but who controls them and who shapes their environmental constraints.

Finally, this article does not concern itself with the question of identifying the causal determinants of party strength; it is in this respect a descriptive and not explanatory work. By providing a theoretically-grounded, coherent and harmonised framework to measure party strength, however, it paves the way for further empirical research on this essential topic. Likely candidates for the role as determinants are on the one hand the individual components vis-à-vis overall party strength, and on the other hand classic politological variables of an ideological, sociological, situational and historical kind, such as ideological proximity to the median voter, issue ownership and cleavage formation. ${ }^{37}$

In the following section I will carry out a first testing of the potential and limitations of the proposed framework by applying it to the case study of the evolution of party strength in Germany from 1991 to 2013.

\section{CASE STUDY: PARTY STRENGTH IN UNIFIED GERMANY, 1991-2013}

The past quarter of century has been a period of important transformations for the strength German parties. $^{38}$ Firstly, the traditional two-and-a-half system has been definitively rendered obsolete by the consolidation of two additional parliamentary parties, B90/GRÜNE and DIE LINKE. Secondly, the relative balance of power between parties has experienced substantial short-term and long-term changes. Finally, the declining levels of electoral participation, party membership and public satisfaction have tended to erode the legitimacy of German parties, particularly the traditionally dominant ones, fuelling a large literature on the crisis of parties and on political disaffection (Politikverdrossenheit). ${ }^{39}$ This section will show how a systematic quantitative analysis of party strength can provide the foundations of a more accurate understanding of these phenomena.

\section{Methodological Remarks}

The case study refers to German political parties over the period 1991-2013. The choice of the country is mainly motivated by the relative stability and pervasive state regulation of political parties in Germany, which allows testing the framework in a consistent manner and with data of a good reliability, coverage and quality. The timeframe coincides the post-unification history of the Federal Republic of Germany. 
The dataset includes a total of 187 parties, only a minority of which have taken part in federal elections (62), have been represented in a state (16) or federal (6) parliament and have participated to a state (9) or federal (5) government. The data for the electoral and governance components include all parties which ever participated to German elections or had a public official elected in the period concerned. The data for the participatory and financial components are limited to 41 parties only, due to a lack of reliable sources; the total membership and financial figures for the missing cases, however, are almost certainly of a negligible magnitude.

The indicators of party strength are built as follows. The composite indicators of governance strength are built by combining the relevant parliamentary seats in Bundestag, in the Bundesrat and in the Landtage at both governmental and parliamentary level. The relative weights of the three bodies have been set at 60 per cent, 6.7 per cent and 33.3 per cent. The relative weight of the parliamentary and governmental sub-components of each body instead varies: if the cabinet enjoys a parliamentary majority, government-supporting seats (including externally supporting parties) are weighted 80 per cent and parliamentary seats 20 per cent; if the cabinet is a minority one, the weights are reversed. The sources for the data are official federal and regional sources and other websites. The composite indicators of electoral strength are built by combining the list votes (Zweitstimme) for the national parliament (Bundestag) and those for the regional assemblies (Landtage), with minor adaptation in the cases of Bayern, Hamburg and Bremen. The weights are set at 60 per cent to the former and 40 per cent to the latter. The source for the data is the official Federal Returning Officer. ${ }^{40}$ The simple indicators of participatory strength are built by adding to the semi-official figures of Niedermayer for the main 6 parties ${ }^{41}$ to the membership figures of 35 minor parties as declared in their financial statements or as estimated. The simple indicators of financial strength, finally, are built by adding together official figures or estimates for net assets of the previous year, yearly incomes of the party organisation, yearly incomes of party foundations and of national and regional parliamentary groups (detracting retained past incomes), and the discretionary incomes of national and regional party MPs (basic salary plus allowances for expenses and collaborators). The method leads to some double-counting to the detriment of the largest parties (contributions and donations to the party by its elected representatives or employees) but also fails to include some of their actual incomes (e.g. salaries of executive officials and external incomes of party-owned companies). The totals are almost three times higher (366.5 per cent) than the commonly-used figures referring to the party-organisation level only. The sources for the data are the official financial statements of parties and parliamentary groups and federal and regional budgets. The composite indicators of overall strength, finally, are build with simple averages of the four above-mentioned components.

The concrete weighting of the different levels and bodies of a given political system in view of the construction of composite indicators inevitably retains a certain degree of arbitrariness, as the literature does not offer a commonly accepted method to estimate their relative importance. On the basis on a variety of quantitative and qualitative facts I propose here provisional proportions that seem to me roughly correspondent to reality and reasonably acceptable by the community of scholars of the German political system. I believe most scholars would be likely to agree on the following principles: (i) the weight of the regional layer in Germany is substantial but smaller than the national one, ${ }^{42}$ hence the choice of a $1 / 3$ to $2 / 3$ ratio; (ii) the role of the Bundesrat is much inferior than that of the Bundestag but not insignificant, ${ }^{43}$ hence a choice of a $1 / 10$ to $9 / 10$ ratio; (iii) governmental 
majorities largely dominate parliaments, except in cases of pure minority cabinets; hence the choice of a reversable $2 / 10$ to $8 / 10$ ratio; (iv) national and regional elections are as important as the body they directly or indirectly contribute to form. ${ }^{44}$ Further research by institutional and policy specialist is however welcome to fine-tune these weights to the German and other national contexts.

All values are based on "rolling" yearly end-year figures; the full dataset with sources and methodological remarks can be accessed on this journal's website. The measures of absolute strength are omitted, as they are not relevant in a single-country analysis.

\section{Systemic Strength}

The post-reunification German party landscape is well known for comprising two major parties (the Christian democratic CDU/CSU and the social democratic SPD), three medium-sized "third parties" (the liberal FDP, the ecologist B90/GRÜNE and the radical left DIE LINKE ${ }^{45}$ ) and a variety of predominantly extra-parliamentary minor organisations. The use of the framework proposed in this article can help identifying with accuracy their relative strength and its variation across components and over time. In particular, it can refine our understanding of the apparent decline of the two main people's parties and of the simultaneous rise of their smaller competitors.

A static analysis of the long-term average values of the indicators of systemic strength over the period 1991-2013 (see Table 2) returns three interesting findings. Firstly, overall systemic strength can be accurately quantified as follows: CDU/CSU 42.8 per cent CSU only 9.2 per cent -, SPD 36.6 per cent, FDP 6.9 per cent, GRÜNE 6.0 per cent, LINKE 4.5 per cent and minor parties 3.4 per cent. The conventional picture based on electoral results is confirmed in its essential traits - ranking and magnitudes - but refined in the details, with gains for the two main parties and losses for all others. Secondly, the balance observable at the national level is not greatly altered by the inclusion of the regional level. The work required by the construction of composite indicators would therefore seem to be almost superfluous in the German case, as simple indicators referring to the sole national level already offer a good approximation of overall values. As I will show below, the discrepancies between the two levels are of little relevance in static terms but substantial in dynamic terms. Nevertheless, the point highlights the relative homogeneity of the German political system, shaped by the presence of durable and cohesive parties and similar electoral laws at both levels of governance. In countries lacking these conditions, France and Italy for instance, discrepancies between levels can be expected to be already visible at the stage of a static analysis. Thirdly, the adoption of a multi-dimensional approach does instead matter. While the ranking of the parties in each component generally remains the same, their relative strength greatly varies: the CDU/CSU from 39.7 (financial) to 47.9 per cent (governance); the SPD from 33.6 (electoral) to 38.8 per cent (participatory); the FDP from 4.2 (participatory) to 8.0 per cent (electoral); the GRÜNE from 2.8 (participatory) to 8.1 per cent (financial); the LINKE from 1.7 (governance) to 6.0 per cent (electoral); and minor parties from 0.2 (governance) to 5.6 per cent (electoral). Generally speaking, the two main parties are favoured in all components except the electoral one, while the governance component penalises LINKE and minor parties, the participatory component FDP and GRÜNE and the financial component minor parties only. 
TABLE 2. SYSTEMIC STRENGTH, 1991-2013 AVERAGE

\begin{tabular}{|c|r|r|r|r|r|r|r|r|}
\hline DIMENSION & $\begin{array}{c}\text { CDU/ } \\
\text { CSU }\end{array}$ & SPD & FDP & GRÜNE & LINKE & MINOR & TOTAL & CSU \\
\hline A. Electoral strength & $\mathbf{3 8 . 9} \%$ & $\mathbf{3 3 . 6 \%}$ & $\mathbf{8 . 0 \%}$ & $\mathbf{7 . 9 \%}$ & $\mathbf{6 . 0 \%}$ & $\mathbf{5 . 6 \%}$ & $\mathbf{1 0 0 . 0 \%}$ & $\mathbf{7 . 4 \%}$ \\
\hline National (60\%) & $37.9 \%$ & $33.9 \%$ & $9.1 \%$ & $7.8 \%$ & $6.4 \%$ & $4.8 \%$ & $100.0 \%$ & $7.3 \%$ \\
\hline Regional (40\%) & $40.5 \%$ & $33.1 \%$ & $6.2 \%$ & $8.0 \%$ & $5.3 \%$ & $6.9 \%$ & $100.0 \%$ & $7.6 \%$ \\
\hline B. Governance strength & $\mathbf{4 7 . 9 \%}$ & $\mathbf{3 7 . 1 \%}$ & $\mathbf{7 . 8 \%}$ & $\mathbf{5 . 2 \%}$ & $\mathbf{1 . 7 \%}$ & $\mathbf{0 . 2} \%$ & $\mathbf{1 0 0 . 0 \%}$ & $\mathbf{1 0 . 2 \%}$ \\
\hline National (60.0\%) & $47.7 \%$ & $36.0 \%$ & $9.7 \%$ & $5.3 \%$ & $1.2 \%$ & $0.0 \%$ & $100.0 \%$ & $8.6 \%$ \\
\hline Gover. coalition & $49.4 \%$ & $36.0 \%$ & $9.9 \%$ & $4.7 \%$ & $0.0 \%$ & $0.0 \%$ & $100.0 \%$ & $8.8 \%$ \\
\hline Parliament & $40.9 \%$ & $36.1 \%$ & $9.2 \%$ & $7.6 \%$ & $6.2 \%$ & $0.0 \%$ & $100.0 \%$ & $7.7 \%$ \\
\hline Bundesrat (6.7\%) & $50.6 \%$ & $39.5 \%$ & $4.5 \%$ & $3.4 \%$ & $1.7 \%$ & $0.3 \%$ & $100.0 \%$ & $9.2 \%$ \\
\hline Regional (33.3\%) & $48.1 \%$ & $38.4 \%$ & $5.1 \%$ & $5.3 \%$ & $2.5 \%$ & $0.5 \%$ & $100.0 \%$ & $13.1 \%$ \\
\hline Gover. Coalitions & $\mathbf{4 8 . 9 \%}$ & $39.5 \%$ & $4.9 \%$ & $4.8 \%$ & $1.7 \%$ & $0.2 \%$ & $100.0 \%$ & $14.2 \%$ \\
\hline Parliaments & $44.1 \%$ & $35.5 \%$ & $5.4 \%$ & $8.0 \%$ & $5.3 \%$ & $1.8 \%$ & $100.0 \%$ & $8.8 \%$ \\
\hline C. Participatory strength & $\mathbf{4 4 . 7 \%}$ & $\mathbf{3 8 . 8 \%}$ & $\mathbf{4 . 2 \%}$ & $\mathbf{2 . 8 \%}$ & $\mathbf{5 . 1 \%}$ & $\mathbf{4 . 3 \%}$ & $\mathbf{1 0 0 . 0 \%}$ & $\mathbf{1 0 . 1 \%}$ \\
\hline D. Financial strength & $\mathbf{3 9 . 7 \%}$ & $\mathbf{3 6 . 9 \%}$ & $\mathbf{7 . 8 \%}$ & $\mathbf{8 . 1 \%}$ & $\mathbf{5 . 5 \%}$ & $\mathbf{2 . 0 \%}$ & $\mathbf{1 0 0 . 0 \%}$ & $\mathbf{9 . 0 \%}$ \\
\hline Overall strength & $\mathbf{4 2 . 8 \%}$ & $\mathbf{3 6 . 6 \%}$ & $\mathbf{7 . 0 \%}$ & $\mathbf{6 . 0 \%}$ & $\mathbf{4 . 6 \%}$ & $\mathbf{3 . 0 \%}$ & $\mathbf{1 0 0 . 0 \%}$ & $\mathbf{9 . 2 \%}$ \\
\hline
\end{tabular}

A dynamic analysis of the short-term variations of the indicators further highlights the advantages of adopting a multi-level and a multi-dimensional approach. On the first account, the national and regional level are asynchronous and their values thus diverge substantially at specific points of time. Regional elections and parliaments are particularly important for territorial or quasi-territorial parties (e.g. CSU in Bavaria, PDS in the former GDR territory and SSW in Schleswig-Holstein), for emerging organisations striving to establish themselves as credible national political forces (e.g. far right organisations, PIRATEN and AfD), for medium parties trying to recover from severe national defeats (GRÜNE after 1990, LINKE after 2002 and FDP after 2013), for one of the two major parties when confined to the opposition at the federal level and for building the momentum of major electoral shifts (e.g. SPD in the mid-1990s, CDU and LINKE in the mid-2000s). The leaning of regional governments, in turn, is normally very different from that of the national one. ${ }^{46}$ On the second account, the various components of systemic weight do not necessarily move in unison. This is well exemplified by the case of the CDU/CSU (Figure 1): its electoral strength has proceeded until 2012 along a broadly declining trajectory, its financial strength has remained remarkably stable, its participatory strength has gradually increased and its governmental weight has followed a pendulum-like movement, with major shifts in the alternation years. 
FIGURE 1. SYSTEMIC STRENGTH, CDU/CSU

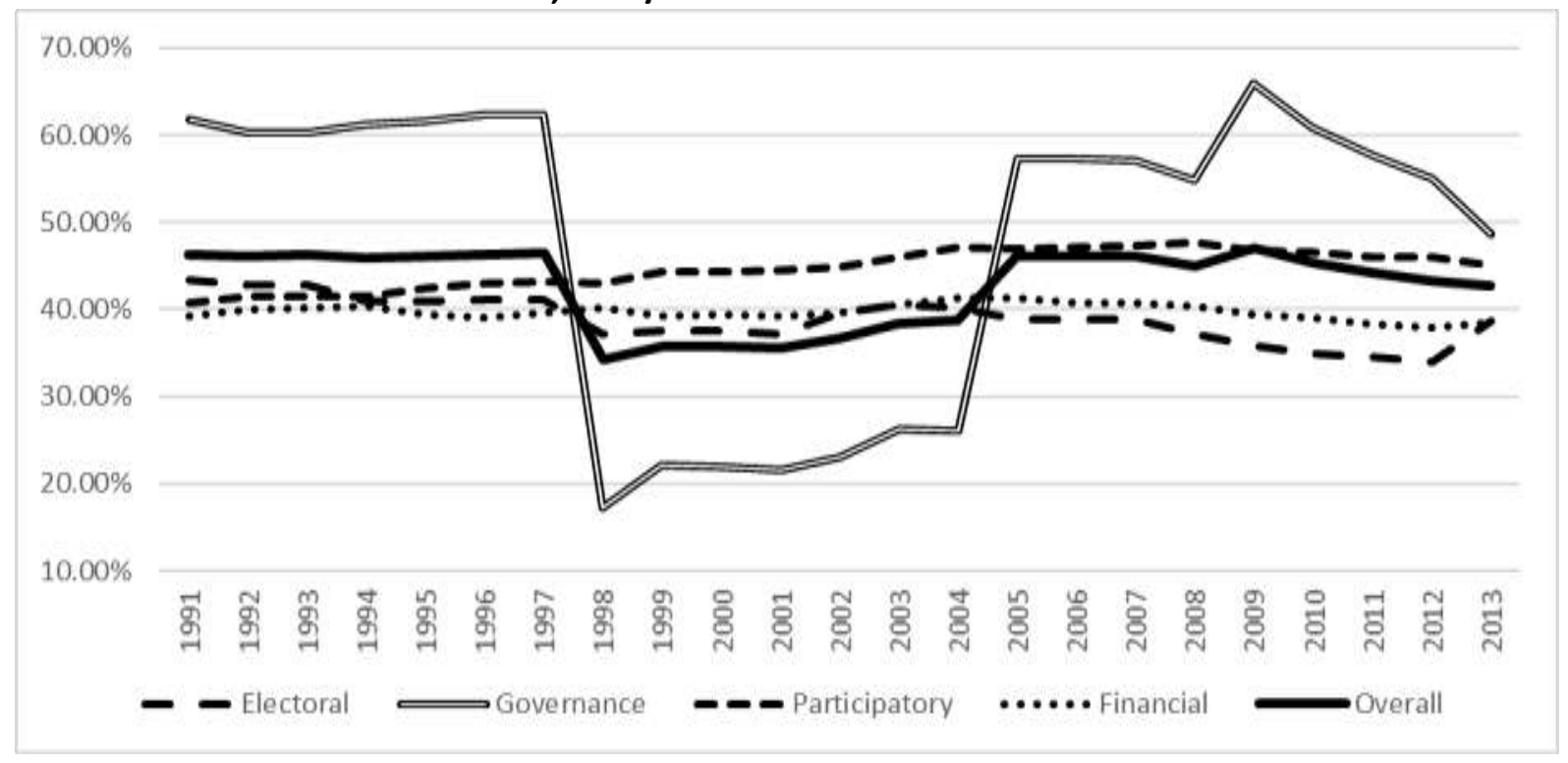

The study of each individual component offers further findings on the changes affecting the German party system over the last decades.

The electoral arena is the place where the malaise of the German Volksparteien has expressed itself most forcefully. Over the whole period the CDU/CSU ranked first (38.9 per cent) and the SPD a not-so-distant second (33.6 per cent), while all other parties were left much behind (FDP 8.0 per cent, GRÜNE 7.9 per cent, LINKE 6.0 per cent, minor parties 5.6 per cent). The combined vote share of the two main parties, which had already fallen from over 90 percent in the 1970s to 78.6 per cent in 1991, declined slightly until 2002 (77.0 per cent) and collapsed to 59.0 per cent in 2012, before recovering to 65.8 per cent in 2013 . In the decade 2002-2012 smaller parties were able to grow at their expense; CDU/CSU and to a less extent the SPD, however, have demonstrated in the 2013 general election that their death knell has not yet sounded.

The distribution of governance strength is very different, strongly favouring the two largest parties and penalising the others, with the exception of the liberals. Over the whole period the CDU/CSU came close to an absolute majority (47.9 per cent); the SPD was a far second (37.1 per cent) followed by FDP (7.8 per cent), GRÜNE (5.2 per cent), LINKE (1.7 per cent) and minor parties ( 0.2 per cent). The main determinant of these disproportionalities are the $5 \%$ electoral thresholds and prevailing patterns of governmental formation: the former makes it very difficult for minor parties to access parliaments ${ }^{47}$ and excludes even medium parties from a number of regional assemblies; the latter further penalises LINKE and minor parties, which are rarely considered as viable coalition partners. ${ }^{48}$ The evolution of governance strength over time was very dynamic, with huge swings at every national governmental alternation (1998, 2005, 2009 and 2013). The combined share of the two main parties has not followed a uniform declining tendency (85.5 per cent in 1991, 92.8 per cent in 2005, 74.7 per cent in 2009, 88.8 per cent in 2013), because the progressive loss of parliamentary seats has been compensated by an increase of the frequency of grand coalition governments. This is mainly a consequence of the behaviour of the national SPD which, when faced with notional centre-left parliamentary majorities, has generally preferred to govern with the CDU (2005-2009, 2013-present) rather than experiment with red-red-green coalitions. ${ }^{49}$ The growth of medium and minor parties has been steady at the 
regional level but fickle at the national and Bundesrat ones, determining a trendless overall effect.

The participatory component, surprisingly, also contradicts the perception of a crisis of the two dominant parties. In average, the participatory balance of power favoured CDU/CDU (44.7 per cent) and SPD (38.8 per cent) and downsized all other parties. The ranking also changed: DIE LINKE came third (5.1 per cent), FDP fourth (4.2 per cent), GRÜNE a poor fifth ( 2.8 per cent) and minor parties showed a surprising strength (4.3 per cent). Interestingly, the gap between first and second was initially inexistent but dramatically widened afterwards. ${ }^{50}$ Although the data should be taken with some caution, as the members of the larger parties are known to be less active than those of smaller ones, ${ }^{51}$ the advantage of the people's parties in this component remains unquestionable. Their combined membership weight actually increased from 80.8 per cent in 1991 to 85.3 per cent in 2001, before slowly falling back to 79.9 per cent in 2013.

The financial component favours the SPD, penalises minor parties and leaves the values of all other parties fairly unchanged. The distribution of resources is remarkably similar to that of the parliamentary sub-component of governance strength: this is hardly surprising, as 31.1 per cent of the total resources derive from elected representatives and their parliamentary groups and 22.6 per cent from party-near political foundations (which obtain state funding in a manner roughly proportional to the medium-term parliamentary strength of their parties). The remaining portion ( 46.3 per cent) is represented by incomes and net assets of the party-organisation, of which slightly less than half can be estimated to derive from state funding highly proportional to electoral results. Over the whole period the CDU/CSU (39.7 per cent) had a slight advantage over the SPD (36.9 per cent), followed by GRÜNE (8.1 per cent), FDP (7.8 per cent), LINKE (5.5 per cent) and minor parties (2.0 per cent). The combined weight of the two main parties remained stable from 1991 (77.5 per cent) to 2005 (77.9 per cent) but declined afterwards (2013: 71.0 per cent).

Finally, the evolution of the 4-item composite indicator of overall systemic strength is depicted in the following figures (Figure 2 and Figure 3). The measure seems to capture well all major elements of change in the distribution of systemic weight among German parties underlined by the quantitative and qualitative literature: the importance of national governmental alternations (1998, 2005, 2009 and 2013), the accelerating crisis of the SPD in the period 2002-2009, the rise of minor parties in the years of economic storm (2007-2012), the relative stabilisation of 2013 and the unstable trajectories of FDP, GRÜNE and PDS/DIE LINKE. From a statistical point of view, this measure shows neither too strong nor too weak a correlation with the vote share, the most used measure of party strength, thus proving its usefulness as a new synthetic indicator operationalising this concept. ${ }^{52}$ 
FIGURE 2. OVERALL SYSTEMIC STRENGTH, LARGE PARTIES

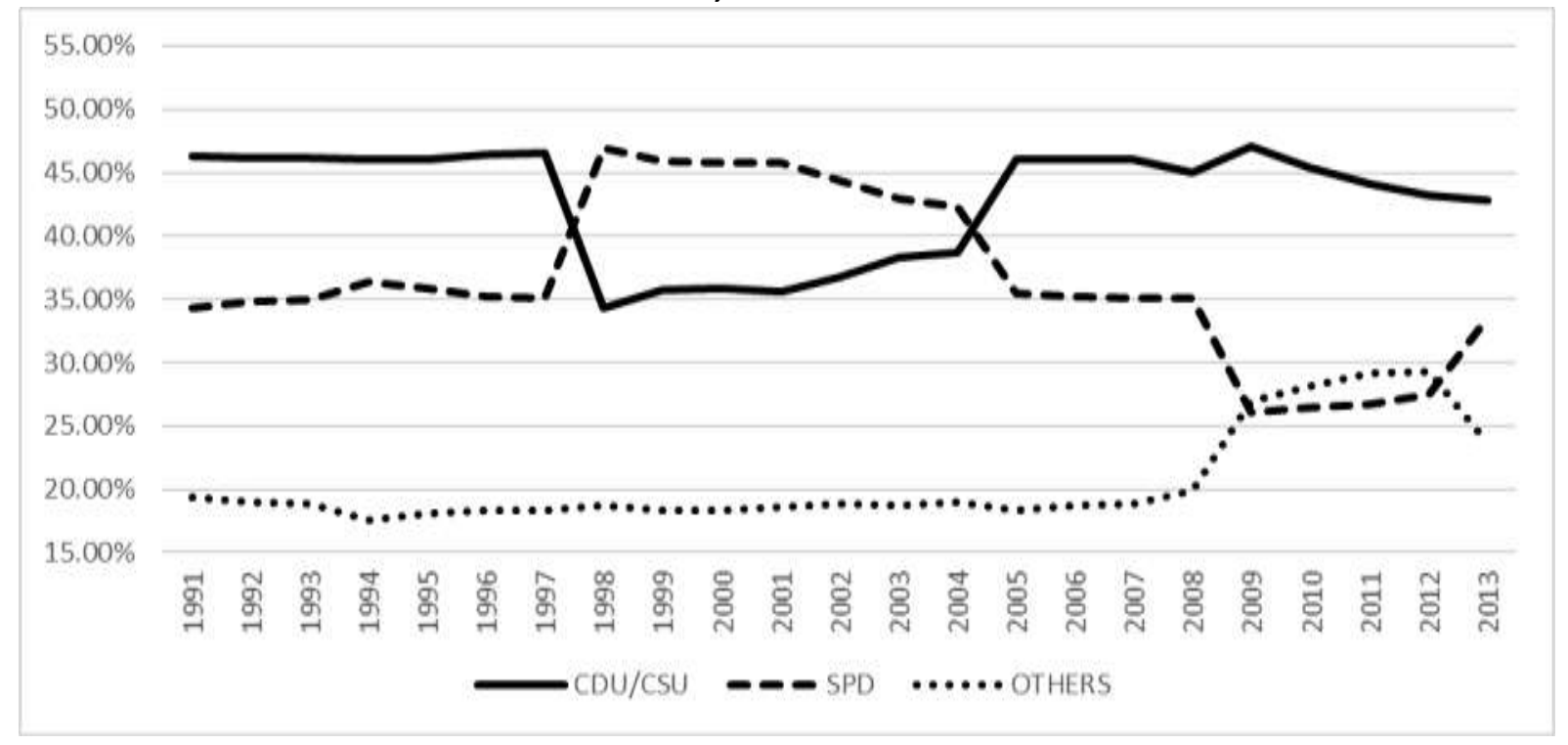

FIGURE 3. OVERALL SYSTEMIC STRENGTH, SMALLER PARTIES

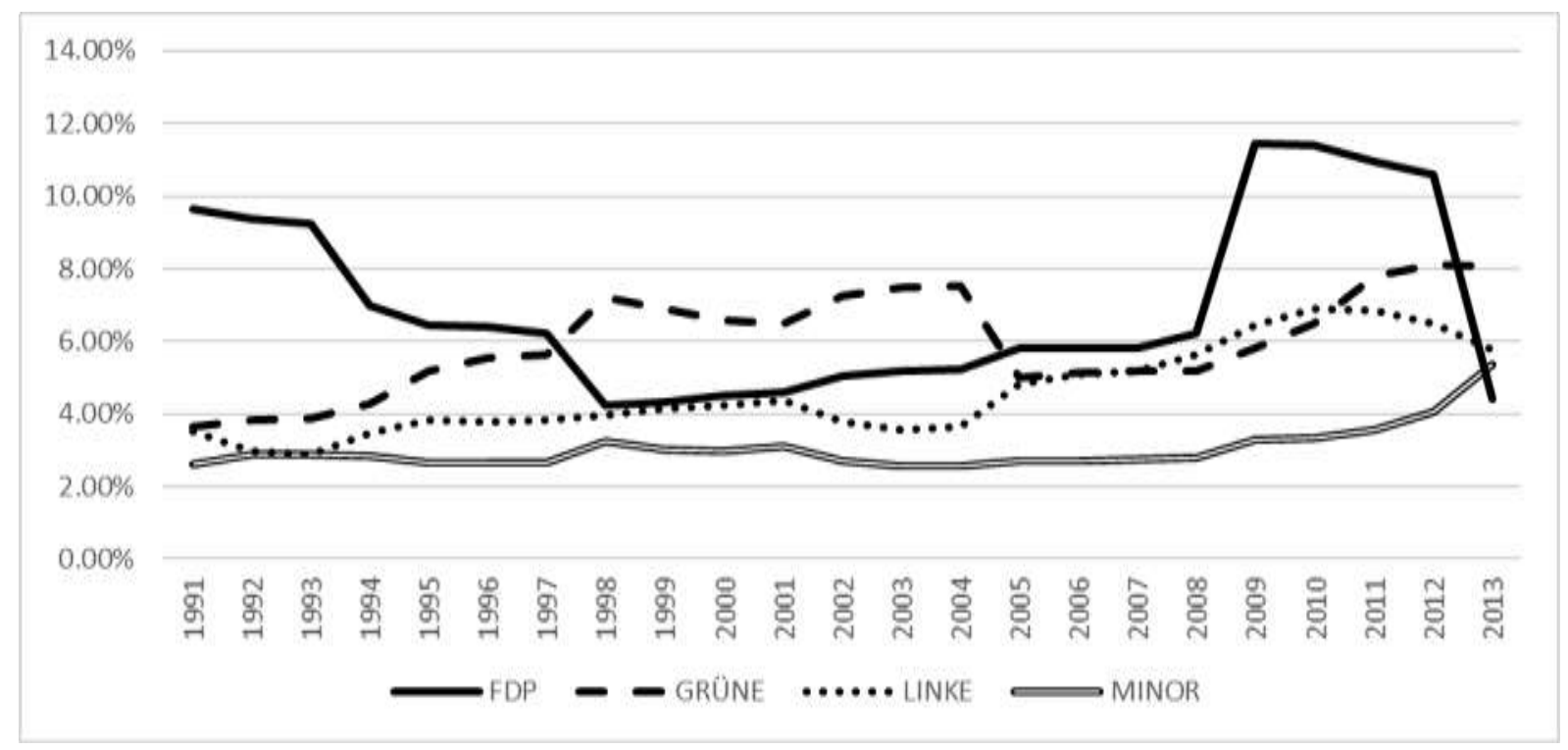

On the basis of the preceding analysis it is possible to propose a periodisation of the recent evolution of the German party system into three clear phases.

The first phase, lasting from 1990 to 2002, was characterised by a remarkably stable predominance of the two main parties (combined overall weight of over 80 per cent) within a pattern of periodic alternation (swing toward the SPD in 1998, slow recovery of the CDU/CSU afterwards).

The second phase, from 2002 to 2012, saw instead the build-up of a strong challenge to the predominance of the two main parties. Their combined values fell strongly in the electoral component (-18.0 points) and more moderately in the financial (-8.0 points) and participatory $(-4.0)$ ones. The formation of traditional one-and-a-half governmental majorities (CDU/CSU and FDP, SPD and Greens, SPD and FDP) became increasingly difficult. CDU/CSU and SPD managed to soften the consequences of these trends only by 
monopolising the access to government through the increasingly frequent practice of grand coalitions at the national and regional level. Their governance strength thus actually rose in the period of the second "grand coalition" (2005-2008), before falling precipitously in the years of the black-yellow government (2009-2012) - with total loss of -12.2 points. The overall strength, finally, saw a total loss of 10.5 points to a trough of 70.7 per cent in 2012 . The roots of this crisis were multiple: the progressive turn of the SPD toward hard neoliberal solutions in socio-economic policy, which destabilised its traditional voters and members and turned them toward disengagement or alternative options, notably the Left Party; ${ }^{53}$ the suspension of the traditional alternation in the years 2005-2008; the effects of the economic crisis; and the unprecedented success of medium and minor parties in gaining the ownership of burning political issues such as social justice, environmentalism, digital rights, the eurocrisis and immigration. ${ }^{54}$

The third phase, begun in 2013 , is still difficult to assess. The two main parties, particularly the CDU/CSU, have pulled off a surprising recovery at the September 2013 federal election, and their overall systemic strength has risen again to historically low but substantial levels (76.4 per cent). This may soon prove to be a merely temporary parenthesis of an inevitable long-term decline: various signals seem to point this way, most importantly the perspective of a long period of blocked competition and permanent grand coalition governments (to the hostility between SPD and DIE LINKE at the federal level, which has made this outcome increasingly likely since 2005, was added in 2013 the collapse of the FDP, which deprived the CSU/CSU of its traditional junior partner). However, Poguntke's diagnosis that the people's parties are "losing their dominant position within the German party system", marking a "normalisation of German party politics", 55 seems to have been way too premature, especially when compared with the much more advanced crisis of traditional bipartism in countries such as Greece, Spain and France.

\section{Societal Strength}

A shift of attention from systemic to societal strength allows one to assess the strength of German parties in relation to society at large. From this standpoint, all the familiar signs emphasised by the literature on the crisis of political parties reappear with unequivocal force.

In static terms, German parties retain an acceptable level of societal strength (see Table 3). Over the whole period their total electoral strength stood at 71.1 per cent; their participatory strength at 2.81 per cent; their governance strength at 46.6 per cent and their financial strength at 0.072 per cent. These values are broadly in line with contemporary Western European standards (probably higher in terms electoral and financial terms and lower in participatory terms) and do not point to any deep crisis of legitimacy, external power or internal organisation. 
TABLE 3. SOCIETAL STRENGTH, 1991-2013 AVERAGE

\begin{tabular}{|l|r|r|r|r|r|r|r|r|}
\hline \multicolumn{1}{|c|}{ DIMENSION } & $\begin{array}{c}\text { CDU/ } \\
\text { CSU }\end{array}$ & SPD & FDP & GRÜNE & LINKE & MINOR & TOTAL & CSU \\
\hline A. Electoral strength & $27.7 \%$ & $24.0 \%$ & $5.6 \%$ & $5.6 \%$ & $4.2 \%$ & $4.0 \%$ & $71.1 \%$ & $5.3 \%$ \\
\hline B. Governance strength & $22.4 \%$ & $17.3 \%$ & $3.7 \%$ & $2.4 \%$ & $0.8 \%$ & $0.1 \%$ & $46.6 \%$ & $4.7 \%$ \\
\hline C. Participatory strength & $1.25 \%$ & $1.10 \%$ & $0.12 \%$ & $0.08 \%$ & $0.15 \%$ & $0.12 \%$ & $2.81 \%$ & $0.28 \%$ \\
\hline D. Financial strength & $0.029 \%$ & $0.027 \%$ & $0.006 \%$ & $0.006 \%$ & $0.004 \%$ & $0.001 \%$ & $0.072 \%$ & $0.006 \%$ \\
\hline
\end{tabular}

In dynamic terms, however, the tendency toward a loss of societal strength is unmistakable (see Figure 4). Between 1991 and 2013 the electoral indicator has lost 10.5 per cent of its value, the governance indicator 3.7 per cent, the financial indicator 7.7 per cent and the participatory indicator a staggering 42.1 per cent; the result has been a fall of the indicator of overall strength by 16.0 per cent. The negative trend has been without exceptions in terms of participatory strength, concentrated in the years 2002-2009 in terms of electoral strength, and fairly discontinuous in terms of governance and financial strength. In other words, the German parties have been suffering of a large exit of their members and voters, while their control over financial resources and over the state institutions has oscillated without experiencing an unambiguous downward trend. For scholars attached to "strong" conceptions of democracy focusing on electoral and participatory linkages these findings are disturbing, as they broadly confirm that movement of parties from accountable agents of civil society to unresponsive appendages the state emphasised by Katz and Mair ${ }^{56}$ which might be undermining their legitimacy and the very essence of modern popular sovereignty. ${ }^{57}$ This is not necessarily the view of social and partisan elites, who may even see the growing political disengagement of the citizenry as an opportunity to govern unencumbered by excessive popular demands, provided that this does not result in a substantial rise of populist challengers or anti-parliamentary movements. So far, the declining electoral, institutional and participatory representativeness of German parties has not (yet) fundamentally threatened their ability of carrying on with "politics as usual".

FIGURE 4. OVERALL SOCIETAL STRENGTH, ALL PARTIES (INDEX 1991 = 100)

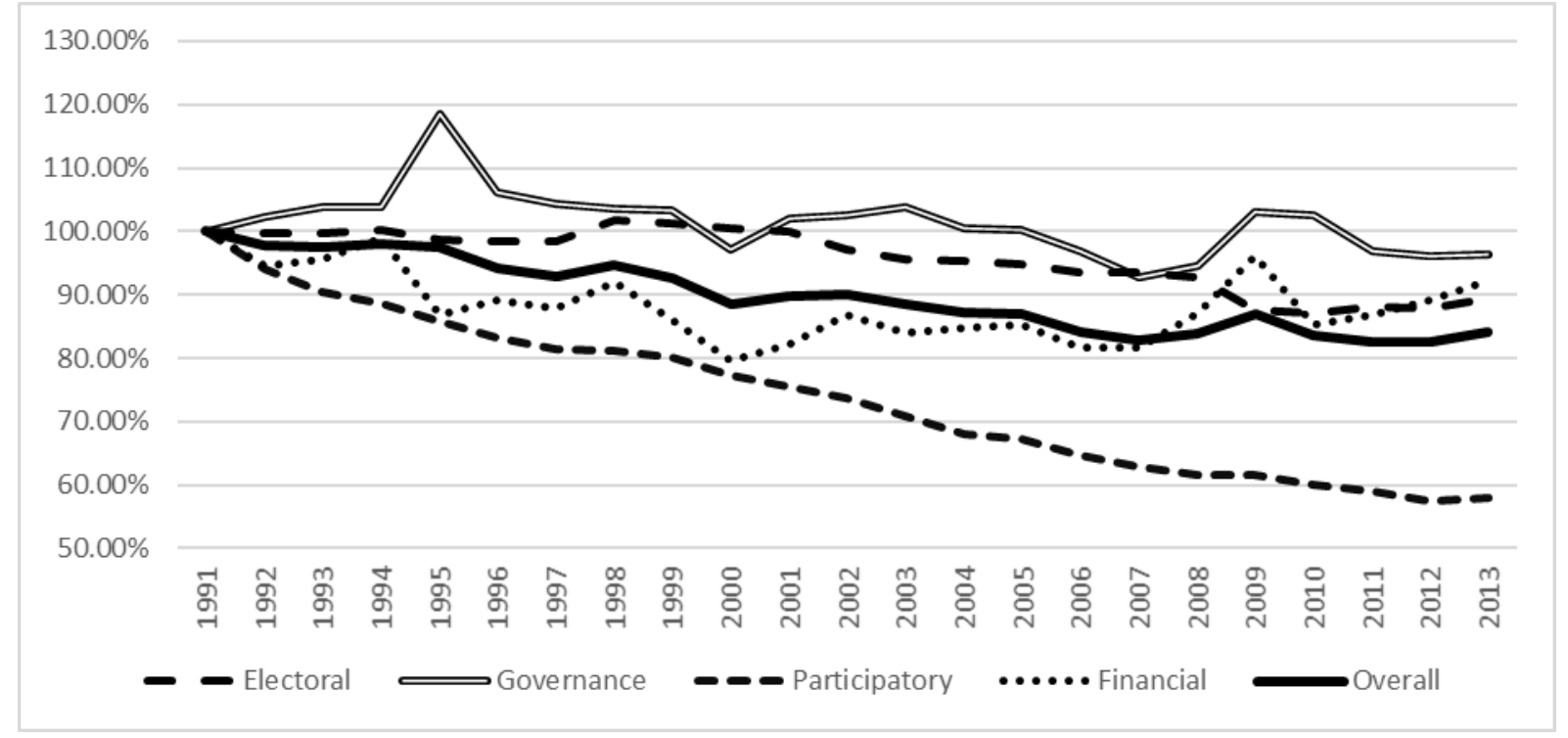




\section{CONCLUSIONS}

This article has presented a new systematic framework for operationalising and measuring party strength, defined in terms of acquisition of power resources. The approach has been then tested on the case study of the evolution of German parties between 1990 and 2013.

The proposed framework enables a reasonable operationalisation and an accurate and coherent measurement of the levels and variations of party strength: a) in absolute terms (absolute strength), vis-à-vis the party system (systemic strength) and vis-à-vis society as a whole (societal strength); b) across four components (electoral, governance, participatory and financial) and in overall terms; c) over time. The problems of the existing scholarship on the topic are addressed by providing a toolkit of fourteen improved and harmonised indicators of party strength, thereby offering a firmer foundation for the analysis of a wide range of aspects of party politics. The main limit of the framework is its failure to account for some important components of party strength: communication resources, collateral linkages and presence within non-elective sections of the state. This is due to the conceptual and practical obstacles to their operationalization into quantitative indicators. One important future avenue of research, therefore, will concern the possibility of developing meaningful "proxy" indicators in these areas. The accuracy and heuristic value of the findings also critically hinges on the reasonableness of the choices made in weighting the various subsets of resources (e.g. national and regional level, institutional bodies) and components; more work is thus needed on adapting the model and testing it in comparative empirical studies.

The empirical analysis of the German case has shown that the framework captures well the key phenomena identified by existing qualitative and quantitative research: the centrality of CDU/CSU and to a less extent SPD in the German party system; their relative decline over time vis-à-vis medium and small competitors; the importance of alternation years; the general crisis of attractiveness of parties vis-à-vis society at large. At the same time, the tools used enable a more refined understanding of these dynamics. Firstly, from 1991 to 2013 the overall societal strength of all German parties has declined strongly but not dramatically (-16.0 per cent). The veritable collapse in the participatory component has been accompanied by more moderate and irregular declines in the electoral and financial components and by a virtual stability of the governance one. Although the downward trajectory is unmistakeable, both average and end-period levels do not yet indicate a state of advanced crisis of German parties, which can still count on the electoral support of a large majority of citizens and on a comparatively substantial amount of financial and institutional resources. Secondly, in the same period the balance of systemic strength has tended to shift away from the two main parties (CDU/CSU and SPD) and toward alternative options, but again not to the point of fundamentally threatening their dominance. The overall strength of medium and small parties actually remained stable around 18-19 per cent until 2007; the strong gains of the subsequent period (2012: 29.3 per cent) were partially reversed in 2013 ( 23.6 per cent). The relative decline of the people's parties was strong at the electoral level (12.8 percentage points), more modest at the financial one (-6.5 percentage points) and absent in the other two components. Although the long-term tendency toward an increasing fragmentation of the German party system is likely to reassert itself after the reversal of the 2013 federal election, CDU/CSU and SPD continue to exhibit a clear predominance and no fundamental break of this state is in the cards for the foreseeable future. Thirdly, the 
electoral weakening of the people's parties, far from leading toward an opening of the competition and of the politics of alliances, has actually led them to try to balance their losses by monopolising their control on executive offices. The fundamental shift in the dynamics of the system happened in the years 2002-2005, when the weakening of the SPD and the simultaneous rise of the radical left (PDS in the East, WASG in the West) largely destroyed the previous pattern of bi-polar alternation. The result has been a predominant pattern of grand coalition governments at the national (2005-2009, 2013-present) and regional (in the East and in Saarland) level, which shored up the role of CDU/CSU and SPD in the short-term but is likely to encourage new party births and further fragmentation in the medium-term. 


\section{Notes:}

${ }^{1}$ Peter Mair, 'Ruling the void. The hollowing of Western democracy', New Left Review 42 (2006), pp. 25-51.

2 Russell J. Dalton and Martin P. Wattenberg (eds), Parties without partisans. Political change in advanced Western democracies (Oxford: Oxford University Press, 2002); Russell J. Dalton, David M. Farrell and lan McAllister, Political parties and democratic linkage (Oxford: Oxford University Press, 2011).

${ }^{3}$ Wolfgang C. Müller and Kaare Strøm, 'Political parties and hard choices', in Wolfgang C. Müller and Kaare Strøm (eds), Policy, office or votes? (Cambridge: Cambridge University Press, 1999), pp.1-35.

${ }^{4}$ Robert Harmel and Kenneth Janda, 'An integrated theory of party goals and party change', Journal of Theoretical Politics, 6/3 (1994), pp.259-87.

${ }^{5}$ Müller and Strøm, 'Political parties and hard choices', p.9.

${ }^{6}$ Common reasons of such a choice are internal factionalism, the independent-mindedness of activists, the opportunity to increase the membership and the electoral attractiveness of the organisation, state regulations or ideological-strategical motivations.

an essential precondition for the realisation of the policy objectives of the party)

${ }^{7}$ Angelo Panebianco, Political parties: organization and power (Cambridge: Cambridge University Press), p.235.

8 Ian Budge and Michael Laver, 'Office seeking and policy pursuit in coalition theory', Legislative Studies Quarterly, 11/4 (1986), p.490.

${ }^{9}$ For a similar distinction between pursuing the "public good" and rent-seeking see for instance: Ingrid van Biezen and Petr Kopecky, 'The state and the parties: public funding, public regulation and rent-seeking in contemporary democracies', Party politics, 13/2 (2007), pp.235-54.

${ }^{10}$ The classical formulations can be found in Maurice Duverger, Political Parties (New York, NY: Wiley, 1954); Seymour M. Lipset and Stein Rokkan, 'Cleavage structures, party systems, and voter alignments: an introduction', in Seymour M. Lipset and Stein Rokkan (eds) Party systems and voter alignments: cross-national perspectives (New York, NY: The Free Press, 1967); Otto Kirchheimer, 'The Transformation of West European Party Systems', in Joseph LaPalombara and Myron Weiner (eds) Political Parties and Political Development (Cambridge: Princeton University Press, 1966), pp.177-200.

${ }^{11}$ Max Weber, Economy and Society, vol. 1 (New York, NY: Bedminster Press, 1968), p.284.

12 The politological literature however cyclically points out the danger of a degeneration of parties into unresponsive self-serving machines; see for instance Richard S. Katz and Peter Mair, 'Changing models of party organization and party democracy. The emergence of the cartel party', Party Politics 1/1 (1995), pp.5-28.

${ }^{13}$ The concern is here with the power of parties. For a recent excellent discussion of power within parties Danny Rye, Political parties and the concept of power. A theoretical framework (Basingstoke: Palgrave Macmillan, 2014).

${ }^{14}$ Gerald M. Pomper, Voters, elections and parties: the practice of democratic theory (New Brunswick, NJ: Transaction Publishers, 1988).

${ }^{15}$ Michael Gallagher, Michael Laver and Peter Mair, Representative government in modern Europe (London: McGraw-Hill, 2011); Marc Laver, 'Legislatures and parliaments in comparative context', in Barry R. Weingast and Donald A. Wittman (eds.), Oxford handbook of political economy (Oxford: Oxford University Press, 2006), pp.121-140; Peter Kopecky, Peter Mair and Maria Spirova, Party patronage and party government (Oxford: Oxford University Press, 2012).

${ }^{16}$ Richard F. Katz and Peter Mair (eds.), Party organizations: a data handbook on party organizations in Western democracies, 1960-1990 (London: Sage, 1992); Richard F. Katz and Peter Mair 'The membership of political parties in European democracies, 1960-1990', European Journal of Political Research 22 (1992), pp.329-45; Emilie Van Haute, Adhérer à un parti. Aux sources de la participation politique (Bruxelles: Editions de I'Université de Bruxelles, 2009); Thomas Poguntke, 'Party organisational linkage: parties without firm social roots?', in Kurt R. Luther and Ferdinand Müller-Rommel (eds), Political parties in the new Europe. Political and analytical challenges (Oxford: Oxford University Press, 2002); John Hopkin, 'The problem with party finance: theoretical perspectives on the funding of party politics', Party Politics 10/6 (2004), pp.627-51.

${ }^{17}$ Aeron Davis, The mediation of power: a critical introduction (London: Routledge, 2007). 
${ }^{18}$ Bertrand Russell, Power: a new social analysis (London: Allen \& Unwin, 1938), p.18. For more comprehensive reviews of this "essentially contested" concept: Dennis H. Wrong, Power: its forms, bases, and uses (New Brunswick, NJ: Transaction Publishers, 1995); Steven Lukes, Power: a radical view (Basingstoke: Palgrave Macmillan, 2004).

${ }^{19}$ Examples of the ex-post approach are the study of policy outcomes and the study of veto players: Robert Dahl, Who governs? (New Haven, CT: Yale University Press, 1961); George Tsebelis, Veto players: how political institutions work (Princeton, NJ: Princeton University Press, 2002).

20 The choice of yearly rolling figures is the most suitable to my purpose. For more detailed studies it is of course possible to use quarterly or daily rolling figures.

21 “[...] number of party members, number of party activists, number of elected officials, amount of autonomously collected resources, number of controlled source of information, number of controlled 'Quangos' [...], and so on". Piero Ignazi, 'The crisis of parties and the rise of new political parties', Party Politics 2/4 (1996), pp.549-66.

${ }^{22}$ Overall party strength cannot be expressed in absolute terms, as each resource is intrinsically different and incommensurable.

${ }^{23}$ Martin Rosema, 'Partisanship, candidate evaluations, and prospective voting', Electoral studies 25/3, pp.46788.

${ }^{24}$ In particular, reporting discrepancies, the risk of electoral frauds, the number of registered voters (which may substantially differ from that of eligible voters), invalid ballots, special constituencies, parallel voting (where only list votes are usually considered) and the attribution of votes to specific parties (e.g. when parties field joint candidates or lists).

${ }^{25}$ Adrian Blau, 'The effective number of parties at four scales: votes, seats, legislative power and cabinet power', Party Politics 14/2 (2008), pp.167-87; Dennis Leech, 'An empirical comparison of the performance of classical power indices', Political Studies 50/1 (2002), pp.1-22; Eric C. Browne and Mark N. Franklin, 'Aspects of coalition payoffs in European parliamentary democracies', The American Political Science Review 67/2 (1973), pp.453-59; Peter J. Taylor and Arend Lijphart, 'Proportional tenure vs. proportional representation: introducing a new debate', European Journal of Political Research 13/4 (1985), pp.387-99; Jack Vowles, 'Electoral systems and proportional tenure of government: renewing the debate', British Journal of Political Science 34/1 (2004): pp. 166-79;

${ }^{26}$ Browne and Franklin, 'Aspects of coalition payoffs', pp.453-459.

${ }^{27}$ For instance, it might be useful to further graduate the impact of the size of the governmental coalition on the final indicator with a bonus for extra-large majorities (e.g. beyond the thresholds for constitutional reforms) and a more gradual decline in cases of weak majorities or strong minorities.

${ }^{28}$ Van Haute, Adhérer à un parti; Howard L. Reiter, 'Party decline in the West: a skeptic's view', Journal of Theoretical Politics 1/3 (1989), pp. 325-48; Susan E. Scarrow, Beyond party members (Oxford: Oxford University Press, 2014); Anika Gauja, 'The construction of party membership', European Journal of Political Research 54/2 (2015), pp. 232-48.

${ }^{29}$ Karl Heinz Nassmacher, The funding of party competition: political finance in 25 democracies (Baden-Baden: Nomos, 2009).

30 Müller and Strøm, 'Political parties and hard choices'.

31 Ingrid Van Biezen and Thomas Poguntke, 'The decline of membership-based politics', Party Politics 20/2 (2014), pp. 205-216.

32 Piero Ignazi, 'Power and the (il)legitimacy of parties: an unavoidable paradox of contemporary democracy?', Party Politics 20/2 (2014), pp.160-69.

${ }^{33}$ Giovanni Sartori, Parties and party systems (Cambridge: Cambridge University Press, 1976); Leech, 'An empirical comparison of the performance of classical power indices'; Andrea Ceron, 'Inter-factional conflicts and government formation. Do party leaders sort out ideological heterogeneity?', Party Politics (forthcoming).

${ }^{34}$ See note 21.

${ }^{35}$ William R. Schonfeld, 'Political parties: the functional approach and the structural alternative', Comparative politics 15/4 (1983), pp.477-99.

${ }^{36}$ Philippe C. Schmitter, 'Democratic theory and neocorporatist practice', Social Research 50/4 (1983), pp.885928; Kay Lawson and Peter H. Merkl (eds), When parties fail: emerging alternative organisations (Princeton, NJ: Princeton University Press, 1988); Maurizio Calise, Il partito personale. I due corpi del leader (Bari: Laterza, 2010); Duncan McDonnell and Marco Valbruzzi, 'Defining and classifying technocrat-led and technocratic governments', European Journal of Political Research 53/4 (2014), pp.654-71; Ran Hirschl, Towards juristocracy: 
the origins and consequences of the new constitutionalism (Cambridge, MT: Harvard University Press, 2004); Peter Gouvevich, 'The second image reversed: the international sources of domestic politics; International Organisation, 32/4 (1978), pp.881-912; Simon J. Bulmer and Claudio M. Radaelli, 'The Europeanisation of national politics' in Simon J. Bulmer and Christian Lequesne (eds), The member states of the European Union (Oxford: Oxford University Press, 2005); Colin Crouch, Post-democracy (Cambridge: Polity, 2004);

${ }^{37}$ Anthony Downs, An economic theory of democracy (New York, NY: Harper, 1957); Romain Lachat, 'Issue ownership and the vote: the effect of associative and competence ownership on issue voting', Swiss Political Science Review, 20/4 (2014), pp.727-740; Lipset and Stein Rokkan, 'Cleavage structures'.

${ }^{38}$ Franz Decker and Viola Neu (eds.), Handbuch der deutschen Parteien (Wiesbaden: VS, 2007); Uwe Andersen (ed.), Parteien in Deutschland. Krise oder Wandel? (Schwalbach a.T.: Wochenschau Verlag, 2009); Manfred G. Schmidt, Das politische System Deutschlands (München: C.H. Beck, 2011); Thomas Poguntke, 'Toward a new party system: the vanishing hold of the catch-all parties in Germany', Party Politics 20/6 (2014), pp.960-63.

${ }^{39}$ Franz Walter, Im Herbst der Volksparteien? Eine kleine Geschichte von Aufstieg und Rückgang politischer Massenintegration (Bielefeld: Transcript, 2009); Kai Arzheimer, Politikverdrossenheit. Bedeutung, Verwendung und empirische Relevanz eines politikwissenschaftlichen Begriffs (Opladen: Westdeutscher Verlag, 2002).

${ }^{40}$ Bundeswahlleiter, http://www.bundeswahlleiter.de/.

${ }^{41}$ Oskar Niedermayer, 'Parteimitglieder in Deutschland: Version 2014', Arbeitshefte aus dem Otto-Stammer Zentrum, 21 (2014).

42 The Länder control an almost equal share than the state the total budget $(48.8 \%$ of incomes and $47.4 \%$ of expenditures), but a larger part of it is non-discretionary and constrained by national regulations. Their legislative powers are clearly inferior (art. 70-75 GG), but somehow strengthened by the blocking role of the Bundesrat.

${ }^{43}$ This is not officially considered a second chamber and plays no formal role in making or breaking national governments. It nevertheless plays an important role as co-legislator, having a veto power on all Zustimmungsgesetze (in average $50.2 \%$ of the total parliamentary bills, less than that since the federalism reform of 2006). See for instance Schmidt, Das politische System Deutschlands, pp. 202-210.

${ }^{44}$ The weight of regional election is therefore 40 per cent, the sum of the weight of Landtag (33.3 per cent) and Bundesrat (6.7 per cent) seats. Other methods would not lead to very different results, as German citizens vote less in regional than in national elections (the ratio of valid votes is 44.9 to 55.1 per cent) and to a certain degree treat them as "second order elections".

${ }^{45}$ Born in 2007 from the merger of PDS (1990-2004) then Linkspartei.PDS (2005-2006) and WASG (2005-6).

${ }^{46}$ The most extreme cases are the SPD in 1994 (0 per cent national, 63.1 per cent regional) and the CDU in 2003 (0 per cent national, 56.5 per cent regional).

47 In the period 1990-2013 only the main five parties have ever been represented in the Bundestag. Other eleven have managed to gain representation in at least one Landtag: PIRATEN and DVU in four, NPD in two, and SSW, Republikaner, Freie Wähler, STATT-Partei, Schill-Partei, Liste D, AFB and BIW in one.

${ }^{48}$ Minor parties have never participated to a national governmental coalition and only three times to regional ones (STATT, SCHILL and SSW, once each). On the contrary, CDU/CSU and SPD have held all positions of chancellor and regional governor with the exception of the Green Kretschmann in Baden-Württemberg (since 2011) and of two transitional periods of a few days (GRÜNE and FDP).

49 Joachim Raschke and Ralf Tils, 'Die Qual der Wahl: Das Debakel der SPD und strategische Optionen in der Lagerstruktur des deutschen Parteiensystems', Forschungsjournal Neue Soziale Bewegungen 23/1 (2010), pp.11-16.

${ }^{50}$ In 1994 the SPD led by 0.1 points; this was quickly reversed and by 2008 the lead of the CDU/CSU had grown to 11.7 points (10.4 points in 2013).

${ }^{51}$ Tim Spier, Markus Klein and Ulrich von Aleman (eds.), Parteimitglieder in Deutschland (Wiesbaden: VS, 2011).

52 The correlation analysis between electoral strength and overall strength, both expressed as indexes with base-year 1991, returns an intermediate R-squared value of 0.435 (significant at 99 per cent).

53 Tim Spier, Felix Butzlaff, Matthias Micus and Franz Walter (eds.), Die Linkspartei. Zeitgemäße Idee oder Bündnis ohne Zukunft? (Wiesbaden: VS, 2007).

${ }^{54}$ Christian Lahusen and Britta Baumgarten, 'Die Fragilität kollektiven Handelns: Arbeitslosenproteste in Deutschland und Frankreich', Zeitschrift für Soziologie 35/2 (2006), pp.102-119; Silke Keil and Oscar Gabriel, 'The Baden-Württemberg state election of 2011: a political landslide', German Politics 21/2 (2012), pp.239-46; Saskia Ritter, 'Parteigründungen, Wutbürger und soziales Unternehmertum', in Oskar Nietermayer et al. (eds), Abkehr von den Parteien (Wiesbaden: VS, 2013), pp.157-75; Rüdiger Schmitt-Beck, 'Euro-Kritik, 
Wirtschaftspessimisums und Einwangerungsskepsis: Hintergründe des Beinah-Wahlerfolges der Alternative für Deutschland (AfD) bei der Bundestagswahl 2013', Zeitschrift für Parlamentsfragen, 45/1 (2014), pp.94-112.

55 Poguntke, 'Towards a new party system', p.51, p.61.

${ }^{56}$ See note 10.

${ }^{57}$ Mair, 'Ruling the void', pp.25-51. 